\title{
Suppressive effects of simvastatin on the human acute promyelocytic leukemia NB4 cell line through the regulation of the nuclear factor- $\kappa B$ signaling pathway
}

\author{
GUOQIANG QIU $^{1 *}$, XIAOBAO XIE ${ }^{2 *}$, ZHILIN WANG $^{1}$, MEI ZENG $^{3}$, TINGXIU JIANG ${ }^{4}$, \\ ZHILAN ZOU ${ }^{2}$, LI DAI $^{1}$, XIAOYING HUA ${ }^{2}$ and WEIYING GU ${ }^{2}$ \\ ${ }^{1}$ Laboratory of Hematology; ${ }^{2}$ Department of Hematology, The First People's Hospital of Changzhou, \\ Third Affiliated Hospital of Suzhou University, Changzhou, Jiangsu 213003; ${ }^{3}$ Department of Hematology, \\ The First People's Hospital of Kunshan, Kunshan, Jiangsu 215300; ${ }^{4}$ Department of Hematology, \\ Fourth Affiliated Hospital of Guangxi Medical University, Liuzhou, Guangxi 545005, P.R. China
}

Received November 30, 2013; Accepted May 7, 2014

DOI: $10.3892 / \mathrm{ol} .2014 .2204$

\begin{abstract}
The present study examined the effects of simvastatin on the proliferation, apoptosis and gene expression levels involved in the nuclear factor- $\kappa \mathrm{B}(\mathrm{NF}-\kappa \mathrm{B})$ signaling pathway in the human acute promyelocytic leukemia NB4 cell line by methyl thiazolyl tetrazolium assay, flow cytometry and the Human NF- $\kappa$ B Signaling Pathway RT $^{2}$ Profiler ${ }^{\mathrm{TM}}$ PCR Array profiles. The results showed that simvastatin significantly inhibited proliferation and induced apoptosis of the NB4 cells in a time- and dose-dependent manner. Changes were noted in the expression levels of 56 genes involved in the NF- $\kappa \mathrm{B}$ signaling pathways in the NB4 cells treated with $15 \mu \mathrm{m}$ simvastatin at $48 \mathrm{~h}$ post-incubation, among which, 47 genes were downregulated and 9 were upregulated. In conclusion, simvastatin potentially inhibits the proliferation and induces the apoptosis of NB4 cells through the regulation of the expression levels of genes involved in the NF- $\mathrm{B}$ signaling pathway.
\end{abstract}

\section{Introduction}

Statins as a pharmacological inhibitor of 3-hydroxy-3-methylglutaryl-CoAreductase are widely used in the treatment of hypercholesterolemia in humans. Various statins have been shown to exert several beneficial antineoplastic properties,

Correspondence to: Dr Weiying Gu, Department of Hematology, The First People's Hospital of Changzhou, Third Affiliated Hospital of Suzhou University, 185 Juqian Street, Changzhou, Jiangsu 213003, P.R. China

E-mail: guweiying2001@163.com

*Contributed equally

Key words: simvastatin, NB4 cell, NF-кB signaling pathway, proliferation, apoptosis, PCR array including antiproliferative effects on tumor cells, the inhibition of tumor growth, the induction of cell differentiation and apoptosis and the inhibition of the angiogenesis and metastasis of malignant cells, such as breast cancer, leukemia, prostate cancer and colon cancer cells (1-6). Studies that analyzed the use of atorvastatin and fluvastatin in the NB4 acute promyelocytic leukemia (APL) cell line found that the drugs are potent inducers of cell differentiation and apoptosis, establishing the fact that statins demonstrate potent antileukemic properties in vitro and indicating the possibility that statins in combination with all-trans retinoic acid (ATRA) could be effective in overcoming ATRA resistance in the leukemic cells (6). Nuclear factor- $\kappa \mathrm{B}(\mathrm{NF}-\kappa \mathrm{B})$ as a nuclear factor is widely distributed in cells, and acts through regulating cytokines, chemotactic factors, growth factors, adhesion molecules and the gene expression of immunological receptors, and participating in cell differentiation, immunoreaction, inflammation, cell apoptosis and tumor growth in vivo. Therefore, inhibiting the activation of the $\mathrm{NF}-\kappa \mathrm{B}$ signal transduction pathway probably potentiated a novel therapeutic strategy to treat immune disease, inflammation and tumors (7). Inducible drug resistance is a major barrier to effective cancer therapy, and the activation of NF- $\mathrm{BB}$ may aid in the development of chemoresistance (8). In fact, chemotherapeutic agents can themselves activate $\mathrm{NF}-\kappa \mathrm{B}$, resulting in the eventual resistance of the tumor cells to the therapy (8). Several studies have shown that, in UCN-01-treated cells, simvastatin suppressed the activation of $\mathrm{NF}-\kappa \mathrm{B}$ and potentiated the apoptosis induced by doxorubicin, paclitaxel and 5-fluorouracil (9), acting via a Ras farnesylation-associated mechanism to create signaling perturbations, particularly the prevention of Ras and ERK1/2 activation, culminating in the synergistic induction of cell death (10). However, the cytotoxic potency of simvastatin against NB4 cells and the changes in the $\mathrm{NF}-\kappa \mathrm{B}$ signaling pathway are not well clarified.

Therefore, the present study focused on the changes in the expression of the genes involved in the $\mathrm{NF}-\kappa \mathrm{B}$ signaling pathways in NB4 cells treated with simvastatin. The possible anti-leukemia mechanism of simvastatin is also discussed. 


\section{Materials and methods}

Reagents. Simvastatin was obtained as a sodium salt from Merck Chemical Ltd., (Darmstadt, Germany) and dissolved in $99.5 \%$ ethanol to obtain a $1-\mathrm{mM}$ stock solution kept at $-20^{\circ} \mathrm{C}$ and later diluted in media prior to use in culture. The RNeasy ${ }^{\circledR}$ MinElute $^{\mathrm{TM}}$ purified kit was purchased from Qiagen Ltd. (Hilden, Germany). The 2X SuperArray PCR master mix and 96-Well RT ${ }^{2}$ Profiler ${ }^{\mathrm{TM}}$ PCR Array (catalog no. PAHS-058A) were purchased from SABioscience Ltd. (Qiagen Ltd.).

Cell culture and treatment. The human promyelocytic leukemia NB4 cell line (kindly gifted by the Jiangsu Institute of Hematology, Suzhou, Jiangsu, China) was cultured in RPMI 1640 (Gibco Ltd., Paisley, UK) supplemented with 10\% heat-inactivated fetal calf serum (Gibco Ltd, Invitrogen Life Technologies, Carlsbad, CA, USA), $100 \mathrm{U} / \mathrm{ml}$ penicillin and $100 \mu \mathrm{g} / \mathrm{ml}$ streptomycin in a humidified $5 \% \mathrm{CO}_{2}$ atmosphere at $37^{\circ} \mathrm{C}$. Exponentially growing cells were used for all experiments. Simvastatin was diluted with RPMI 1640 medium to the final concentrations of $15 \mu \mathrm{M}(15 \mathrm{SV}), 10 \mu \mathrm{M}$ (10SV) and $5 \mu \mathrm{M}(5 \mathrm{SV})$ for further treatment. The number of cells was determined by counting in a Burker chamber (Haimen Tianlong Experimental Equipment Factory, Haimen, China), and the final NB4 cell concentration was $2 \times 10^{5}$ cells $/ \mathrm{ml}$. For the dose-response studies, the NB4 cells were seeded at $2 \times 10^{5}$ cells $/ \mathrm{ml}$ in 6 -well plastic plates and treated with $15 \mathrm{SV}, 10 \mathrm{SV}$ or $5 \mathrm{SV}$ for a total treatment time of $72 \mathrm{~h}$, taking NB4 cells without any treatment as normal controls. The cells of the different groups at $24 \mathrm{~h}, 48 \mathrm{~h}$, and $72 \mathrm{~h}$ post-incubation were collected for further detection.

MTT Assay. Cell proliferation was assessed using a methyl thiazolyl tetrazolium (MTT) assay. Briefly, the NB4 cells of the various groups with or without the indicated doses of simvastatin were seeded in 96-well flat-bottomed plates (100 ml/well; Falcon; Corning Inc., Corning, NY, USA) at a final concentration of $2 \times 10^{5}$ cells $/ \mathrm{ml}$ for the time indicated. At 24,48 and $72 \mathrm{~h}$ post-incubation, the NB4 cells were incubated with $5 \mathrm{mg} / \mathrm{ml}$ MTT for $4 \mathrm{~h}$ at $37^{\circ} \mathrm{C}$ and then the medium was removed, the cells were solubilized in dimethyl sulfoxide and the absorbance was measured at $570 \mathrm{~nm}$. All samples were run in triplicate. Background absorbance was corrected by subtracting the absorbance values from the wells with media alone (controls). The cell growth inhibition rate was calculated according to the following formula: Cell growth inhibition rate $(\%)=[1-($ absorbance of experimental group - absorbance of blank group) / (absorbance of negative group - absorbance of blank group)].

Observation of morphological changes to NB4 cells. The NB4 cells $\left(2 \times 10^{5} / \mathrm{ml}\right)$ of the various groups were harvested at 24 , 48 and $72 \mathrm{~h}$ post-incubation, washed once in phosphate-buffered saline (PBS), centrifuged at $500 \mathrm{x} g$ on glass slides in a cytospin apparatus (Wescor Inc., Logan, UT, USA), and then fixed and subsequently stained with Wright-Giemsa solution (Nanjing, China). NB4 cell morphology was observed by microscope.

Flow cytometric analysis of NB4 cell apoptosis. Apoptosis assays were performed using an Annexin V-fluorescein

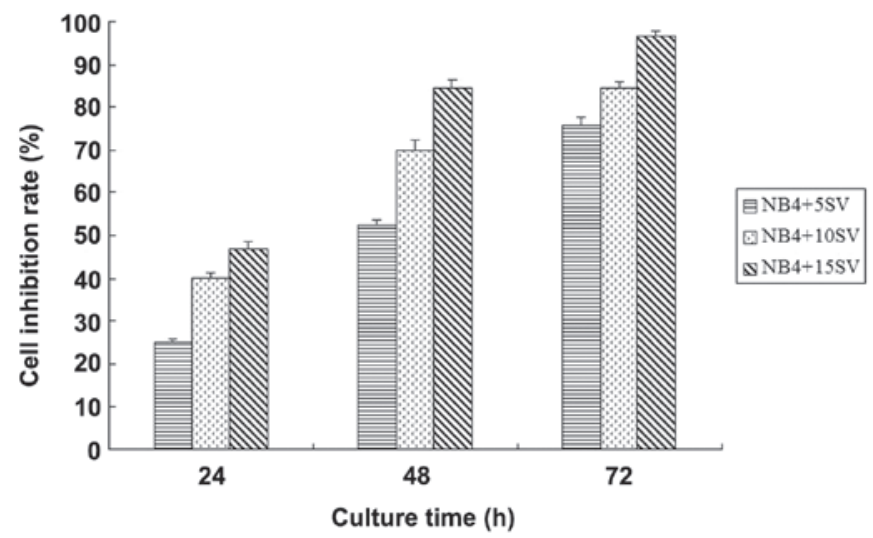

Figure 1. Growth inhibition rate of NB4 cells treated by varying concentrations of simvastatin at $24 \mathrm{~h}, 48 \mathrm{~h}$ and $72 \mathrm{~h}$ post-incubation. $15 \mathrm{SV}, 15 \mu \mathrm{M}$ simvastatin; 10SV, $10 \mu \mathrm{M}$ simvastatin; 5SV, $5 \mu \mathrm{M}$ simvastatin.

isothiocyanate (FITC) Apoptosis Detection Kit (Beyotime Institute of Biotechnology, Shanghai, China) following the manufacturer's instructions, and early apoptosis was evaluated by cytofluorometry (FACScabilur, BD Biosciences, Franklin Lakes, NJ, USA). Following 24, 48 and $72 \mathrm{~h}$ of incubation, the NB4 cells of the various groups were collected and transferred to 5-ml plastic tubes, washed twice with cold PBS, stained with Annexin V-FITC and propidium iodide, and then analyzed by FACScabilur. Samples were run in duplicate with 10,000 events counted per sample. The apoptotic rate was expressed as the mean of three independent experiments.

Human $N F-\kappa B$ signaling pathway detection by $R T^{2}$ Profiler $P C R$ Array. The untreated NB4 cells and those treated with $15 \mathrm{SV}$ were collected at $48 \mathrm{~h}$ post-incubation from three repeated experiments for further NF- $\mathrm{BB}$ signaling pathway detection. Total RNA was extracted from the NB4 cells using the TRIzol one-step procedure according to manufacturer's instructions (Invitrogen Life Technologies), and RNA cleanup was then also performed according to the manufacturer's instructions (RNeasy MinElute; Qiagen Ltd.). cDNA was converted using Superscript III reverse transcriptase. Quantitative PCR was performed according to the $\mathrm{RT}^{2}$ Profiler PCR Array instructions under the following conditions: $95^{\circ} \mathrm{C}$ for $10 \mathrm{~min}$, then $95^{\circ} \mathrm{C}$ for $15 \mathrm{sec}$ and $60^{\circ} \mathrm{C}$ for $1 \mathrm{~min}$. The $\Delta \mathrm{Ct}$ value for each pathway-focused gene was calculated in each treatment group and the $\Delta \Delta \mathrm{Ct}$ method was used to analyze the data.

Statistical methods. Statistical analyses were performed with SPSS software (version 16.0; SPSS, Inc., Chicago, IL, USA). All experiments were performed three times in each individual sample, and the results were presented as the mean value of the three. The Student's t-test was used to compare the means between two groups and one-way analysis of variance was used to compare the means among more than two different groups. $\mathrm{P}<0.05$ was considered to indicate a significant difference.

\section{Results}

Simvastatin inhibits NB4 cell growth. Univariate analysis of variance of the MTT results revealed that when treated 

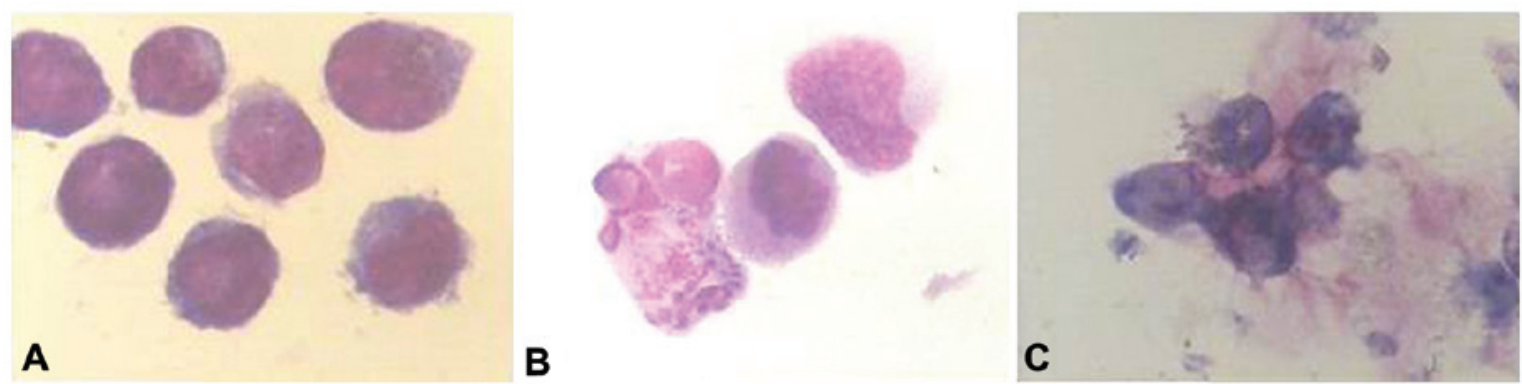

Figure 2. Morphological changes to the NB4 cells treated with simvastatin at the varying concentrations at $48 \mathrm{~h}$ post-incubation (stain, Wright-Gimsa; magnification, x1,000). (A) Normal control NB4 cells. (B) NB4 cells treated with $10 \mu \mathrm{M}$ simvastatin (10SV); apoptotic body formation with an increase in cytoplasm was observed. (C) NB4 cells treated with $15 \mu \mathrm{M}$ simvastatin (15SV); evident karyorrhexis was observed by microscopy.

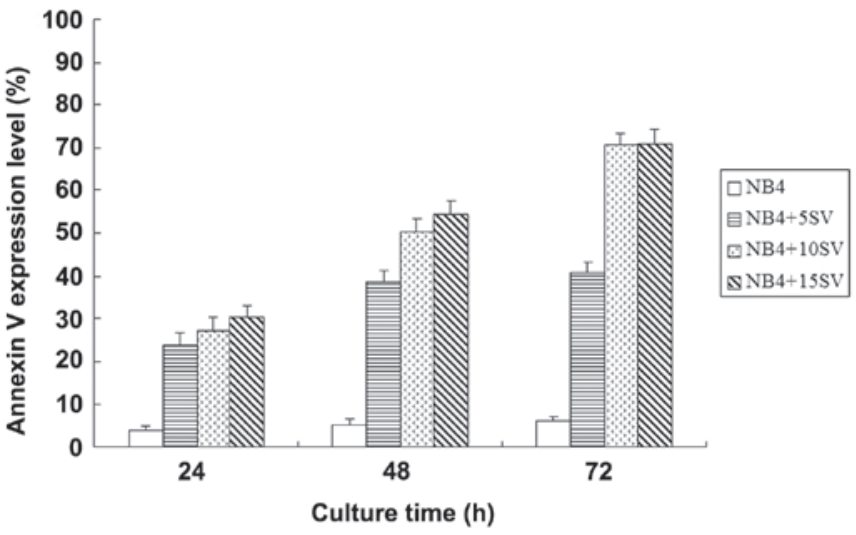

Figure 3. Early-stage apoptotic ratio of NB4 cells treated by the varying concentrations of simvastatin at $24 \mathrm{~h}, 48 \mathrm{~h}$ and $72 \mathrm{~h}$ post-incubation. $15 \mathrm{SV}$, $15 \mu \mathrm{M}$ simvastatin; $10 \mathrm{SV}, 10 \mu \mathrm{M}$ simvastatin; $5 \mathrm{SV}, 5 \mu \mathrm{M}$ simvastatin.

with simvastatin, the NB4 cell growth inhibition rates gradually increased with time $(\mathrm{F}=6.638, \mathrm{P}=0.03)$ and dose $(\mathrm{F}=14.111, \mathrm{P}=0.004)$, indicating that simvastatin potentially inhibits NB4 cell proliferation in a time and dose-dependent manner (Fig. 1).

Morphological changes to NB4 cells treated with simvastatin. The NB4 cells stained by Wright-Giemsa solution exhibited karyorrhexis, petal-like nuclei and apoptotic body formation with increased cytoplasm at 24 and $48 \mathrm{~h}$ post-incubation when treated with simvastatin at the various concentrations. At $72 \mathrm{~h}$ post-incubation with simvastatin, the majority of the NB4 cells manifested karyorrhexis (Fig. 2).

Simvastatin induces NB4 cell apoptosis in a time- and dose-dependent manner. When treated with simvastatin, the Annexin V expression levels of the NB4 cells increased in a time- $(\mathrm{F}=6.909, \mathrm{P}=0.028)$ and dose-dependent $(\mathrm{F}=14.431, \mathrm{P}=0.004)$ manner, and the $15 \mathrm{SV}$ group exhibited the highest level of apoptosis promotion, with the Annexin V expression levels of $70.49 \pm 2.68$ and $70.72 \pm 3.43 \%$ at 48 and $72 \mathrm{~h}$ post-incubation respectively, indicating that simvastatin potentially promotes NB4 cell apoptosis (Figs. 3 and 4). Further t-tests showed that there were no statistical differences $(\mathrm{P}>0.05)$ in the Annexin $\mathrm{V}$ expression levels at 48 and $72 \mathrm{~h}$ in the $5 \mathrm{SV}$ group, therefore, untreated NB4 cells and those treated with $15 \mathrm{SV}$ were used at $48 \mathrm{~h}$
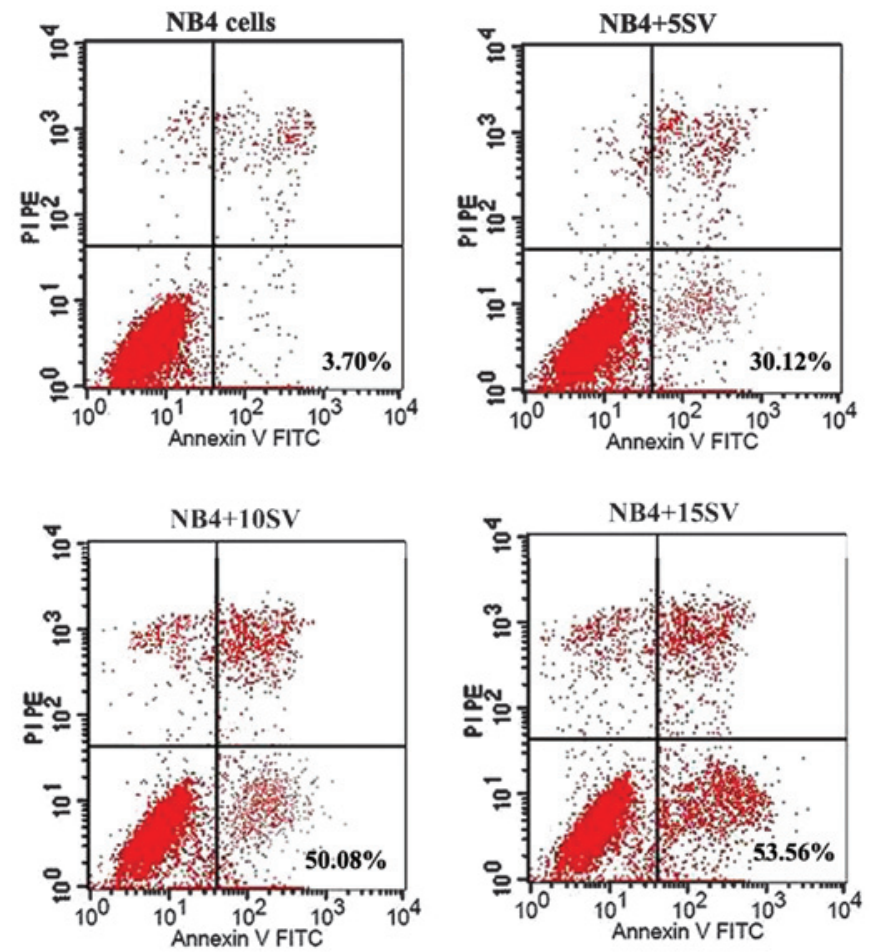

Figure 4. Annexin V expression levels of NB4 cells treated with simvastatin at the varying concentrations at $48 \mathrm{~h}$ post-incubation, as detected by FCM. 15SV, $15 \mu \mathrm{M}$ simvastatin; 10SV, $10 \mu \mathrm{M}$ simvastatin; $5 \mathrm{SV}, 5 \mu \mathrm{M}$ simvastatin; FITC, fluorescein isothiocyanate; PIPE, propidine iodide/phycoerythrin.

post-incubation for human NF- $\mathrm{kB}$ signaling pathway detection by $\mathrm{RT}^{2}$ Profiler ${ }^{\mathrm{TM}}$ PCR Array.

Expression of $N F-\kappa B$ signaling pathway involves genes in $N B 4$ cells treated with simvastatin. Table I shows the changes in the mRNA expression levels of the 84 genes involved in the $\mathrm{NF}-\kappa \mathrm{B}$ signaling pathway. Fold-change $\left(2^{-\Delta \Delta \mathrm{Ct}}\right)$ is measured as the level of normalized gene expression $\left(2^{-\Delta \mathrm{Ct}}\right)$ in the test sample divided by the level of normalized gene expression $\left(2^{-\Delta C t}\right)$ in the control sample. Fold-regulation represents the fold-change results in a biologically meaningful way. When fold-change is $>1$, positive regulation or upregulation is indicated, and the fold-regulation is equal to the fold-change. However, when the fold-change is $<1$, negative regulation or downregulation is indicated, and the fold-regulation is the negative inverse of the fold-change. Table I shows 
Table I. Differentially-expressed genes involved in the NF- $\kappa \mathrm{B}$ signaling pathway of the NB4 cells treated with $15 \mathrm{SV}$ at $48 \mathrm{~h}$ post-incubation.

\begin{tabular}{|c|c|}
\hline Gene & Fold-change of up- or downregulation \\
\hline AGT & -7.19087 \\
\hline AKT1 & -1.34598 \\
\hline ATF1 & 1.932655 \\
\hline BCL10 & 1.015843 \\
\hline $\mathrm{BCL}^{\mathrm{a}}$ & 3.1638 \\
\hline CFB & 1.611881 \\
\hline BIRC2 & 1.168396 \\
\hline NOD1 & 1.352533 \\
\hline CASP1 ${ }^{\mathrm{a}}$ & -2.34227 \\
\hline CASP8 $^{a}$ & 2.42342 \\
\hline CCL2 & -19.4145 \\
\hline CD40 & -1.00316 \\
\hline CFLAR & -1.08346 \\
\hline CHUK & -1.51554 \\
\hline CSF2 & 1.222123 \\
\hline CSF3 & -3.36992 \\
\hline SLC44A2 & -2.71589 \\
\hline EDARADD & -6.09493 \\
\hline LPAR1 & -6.09493 \\
\hline EGR1 & -6.70121 \\
\hline ELK1 & -1.05755 \\
\hline F2R & -3.32772 \\
\hline FADD $^{\mathrm{a}}$ & -1.12544 \\
\hline FASLG $^{\mathrm{a}}$ & -6.09493 \\
\hline FOS & -6.4125 \\
\hline GJA1 & 1.139515 \\
\hline HMOX1 & -25.0176 \\
\hline HTR2B & 1.526521 \\
\hline ICAM1 $^{\mathrm{a}}$ & -87.9626 \\
\hline IFNA1 & 1.179248 \\
\hline IFNB1 & 2.015843 \\
\hline IFNG & -6.09493 \\
\hline IKBKB $^{\mathrm{a}}$ & 1.196008 \\
\hline $\mathrm{IKBKE}^{\mathrm{a}}$ & -1.52768 \\
\hline $\mathrm{IKBKG}^{\mathrm{a}}$ & -1.12064 \\
\hline IL10 $^{\mathrm{a}}$ & -12.9526 \\
\hline $\mathrm{IL}_{1} \mathrm{~A}^{\mathrm{a}}$ & -3.32951 \\
\hline IL1B $^{\mathrm{a}}$ & -72.6281 \\
\hline IL1R $^{a}$ & -8.26226 \\
\hline IL6 $^{\mathrm{a}}$ & -1.72447 \\
\hline IL8 $^{\mathrm{a}}$ & -57.0666 \\
\hline IRAK $1^{\mathrm{a}}$ & 1.346327 \\
\hline 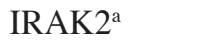 & -31.9603 \\
\hline $\mathrm{JUN}^{\mathrm{a}}$ & -42.4192 \\
\hline $\mathrm{LFA}^{\mathrm{a}}$ & -4.13282 \\
\hline LTBR & 1.432608 \\
\hline MALT1 & -1.72488 \\
\hline MAP3K1 ${ }^{\mathrm{a}}$ & 4.217983 \\
\hline MYD88 ${ }^{\mathrm{a}}$ & -2.82548 \\
\hline NLRP12 & -40.5471 \\
\hline
\end{tabular}

Table I. Continued.

\begin{tabular}{|c|c|}
\hline Gene & Fold-change of up- or downregulation \\
\hline NFKB $1^{\text {a }}$ & -2.77427 \\
\hline $\mathrm{NFKB}^{\mathrm{a}}$ & -3.9451 \\
\hline NFKBIA $^{\mathrm{a}}$ & 7.6537 \\
\hline PPM1A & 1.634145 \\
\hline RAF1 & -1.15277 \\
\hline REL & -1.25596 \\
\hline RELA $^{\mathrm{a}}$ & -1.40901 \\
\hline RELB $^{\mathrm{a}}$ & -1.72021 \\
\hline TRIM13 & 1.162488 \\
\hline RHOA & -2.55771 \\
\hline RIPK1 & -1.75764 \\
\hline SLC20A1 & 2.165973 \\
\hline STAT1 & -1.09569 \\
\hline TBK1 & -1.2594 \\
\hline TICAM2 & -3.75585 \\
\hline TLR $1^{\mathrm{a}}$ & -3.5425 \\
\hline TLR2 $^{\mathrm{a}}$ & -6.09493 \\
\hline TLR3 $^{\mathrm{a}}$ & -1.41519 \\
\hline TLR $^{\mathrm{a}}$ & -2.27636 \\
\hline TLR6 $^{\mathrm{a}}$ & -6.42164 \\
\hline TLR7 $^{\mathrm{a}}$ & 1.196063 \\
\hline TLR $8^{\mathrm{a}}$ & -1.06758 \\
\hline TLR9a & -2.31402 \\
\hline TMED4 & 1.070532 \\
\hline $\mathrm{TNF}^{\mathrm{a}}$ & -22.7788 \\
\hline TNFAIP3 $^{\mathrm{a}}$ & -23.5035 \\
\hline TNFRSF10A & -1.05723 \\
\hline TNFRSF10B $^{\mathrm{a}}$ & -2.53081 \\
\hline TNFRSF1A & 2.346345 \\
\hline CD27 & -2.32356 \\
\hline TNFSF10 & -3.35489 \\
\hline TNFSF14 & -1.17296 \\
\hline TRADD & -1.6789 \\
\hline TICAM1 & -7.99424 \\
\hline
\end{tabular}

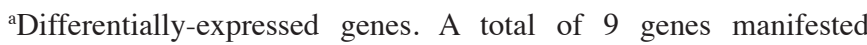
upregulation, including the I $\mathrm{KB}$ family genes, $\mathrm{BCL} 3, \mathrm{I} \kappa \mathrm{B} \alpha$, caspase 8 and IFN $\beta ; 47$ manifested downregulation, including the IKK family genes, the nuclear factor- $\kappa \mathrm{B}(\mathrm{NF}-\kappa \mathrm{B})$ family genes, pro-inflammatory factors such as IL-1, IL-6, IL-8 and TNF, cellular adhesion molecules ICAM/LFA and the toll-like receptor (TLR) pathway, which mediated immune response-associated genes such as the TLR family, MYD88 and IRAK1/2.15SV, $15 \mu \mathrm{M}$ simvastatin.

that, among the 84 genes, the expression levels of 11 genes changed with a fold-difference of 1.5 to 2.0 , and the expression levels of 45 genes manifested fold-change values of $>2.0$. Of the 56 differently-expressed genes, 9 manifested upregulation, including the inhibitory $\kappa \mathrm{B}(\mathrm{I} \kappa \mathrm{B})$ family genes, BCL3, IкB $\alpha$, caspase 8 and IFN $\beta ; 47$ manifested downregulation, including the I $\mathrm{B}$ kinase (IKK) family genes, 
the $\mathrm{NF}-\kappa \mathrm{B}$ family genes, pro-inflammatory factors such as IL-1, IL-6, IL-8 and TNF, cellular adhesion molecule ICAM/ LFA and the toll-like receptor (TLR) pathway, which mediated immune response-associated genes such as TLR family, MYD88 and IL-1 receptor-associated kinase (IRAK)1/2. The changes in the expression of these genes indicated that simvastatin may promote NB4 cell apoptosis by regulating the gene expression involved in TLR and NF- $\kappa \mathrm{B}$ signaling pathways.

\section{Discussion}

Atorvastatin and fluvastatin have previously been demonstrated as potent inducers of cell differentiation and apoptosis in the NB4 cell line (6). In another study, the following cytotoxic potency against HL-60 was found: Simvastatin $(\mathrm{SV})>$ atorvastatin $>$ cerivastatin $>$ fluvastatin. Notably, the all-trans retinoic acid (ATRA)-resistant HL-60 variant, HL-60-R2, was twice as sensitive to SV compared with HL-60. These findings indicated that simvastatin exhibits the most cytotoxic potency against the ATRA-resistant HL-60 variant, which may overcome the ATRA resistance to APL cells (11). The present results showed that simvastatin inhibited NB4 cell growth and promoted cell apoptosis in a time- and dose-dependent manner, as found in the results of a previous study (11). It was also found that the expression levels of 56 genes involved in the NF- $\kappa \mathrm{B}$ signaling pathways were changed in the NB4 cells treated with $15 \mathrm{SV}$ at $48 \mathrm{~h}$ post-incubation, and it was hypothesized that the proapoptotic mechanism may be associated with the changes in the gene expression levels involved in the $\mathrm{NF}-\kappa \mathrm{B}$ signaling pathway regulated by simvastatin. With regard to the underlying proapoptotic dose of simvastatin, it has previously been reported that combining tipifarnib and simvastatin at dose of 5 and $50 \mu \mathrm{M}$, respectively, exhibited a synergistic apoptosis effect in KG1 and TF-1 cells (12). The present study found that $15 \mathrm{SV}$ manifested clear anti-leukemia effects on the NB4 cells, avoiding the side-effects caused by high-dose simvastatin.

The expression of a wide range of genes that are involved in numerous processes, including the inflammatory and immune responses of the cell, cell growth and development, is regulated by the eukaryotic NF- $\mathrm{NB}$ transcription factor family. The involvement of NF- $\kappa \mathrm{B}$-mediated signal transduction has been indicated in the inflammatory response, autoimmune diseases, tumorigenesis, apoptosis and in the regulation of viral replication. NF- $\mathrm{NB}$ transcription factor activation occurs in response to a range of signals, including, pathogens, cytokines, injuries and other stressful conditions. $\mathrm{NF}-\kappa \mathrm{B}$ protein activation is strictly regulated, and inappropriate $\mathrm{NF}-\kappa \mathrm{B}$ signaling pathway activation has been associated with chronic inflammation, autoimmunity and a number of cancer types (13-15). Due to its critical role in cell survival, cell adhesion, inflammation, differentiation and cell growth, $\mathrm{NF}-\kappa \mathrm{B}$ has been indicated to be involved in carcinogenesis.

TLRs are a class of proteins that are required for the host defense against infection. TLRs play a key role in auto-immunity, and are considered to be important recognition and signal transduction receptors (16). MyD88 is a TLR domain-containing cytoplasmic protein. Evidence indicates that all of the TLRs, with the probable exception of TLR3, utilize this pathway. MyD88 interacts with IRAK-4, via their respective death domains. IRAK-4 then recruits IRAK-1 to the complex, leading to its phosphorylation and activation (17). IRAK-1 and IRAK-4 then dissociate from the complex and interact with TNF receptor-associated factor- 6 , which in turn recruits transforming growth factor- $\beta$-activated kinase-1 (TAK-1)-binding protein-1 (TAB-1) and TAB-2 to the complex. This leads to the phosphorylation and activation of the kinase, TAK-1 (18). TAK-1 then activates kinases upstream of p38 and $\mathrm{JNK}$, and the IKK complex, leading to NF- $\kappa \mathrm{B}$ activation and the induction of proinflammatory cytokine expression, including that of IL-1, IL-6, IL-12 and TNF- $\alpha$. Therefore, the TLR/NF- $\kappa$ B signaling pathway upregulates inflammatory cytokine expression, which activates $\mathrm{NF}-\kappa \mathrm{B}$, resulting in cell apoptosis inhibition and subsequent cell immortalization (18). The present results revealed that when treated with $15 \mathrm{SV}$, the mRNA expression levels of the IKK and NF- $\kappa$ B family genes in NB4 cells were all downregulated, however, the expression levels of the I $\mathrm{B}$ family genes, which inhibit $\mathrm{NF}-\kappa \mathrm{B}$ transcriptional activity, were upregulated, indicating that simvastatin promotes NB4 cell apoptosis through the inhibition of cell transcription mediated by NF- $\mathrm{BB}$. Additionally, the present study found that the mRNA expression levels of the pro-inflammatory factors (IL-1, IL-6, IL-8 and TNF), the TLR signaling pathway-associated genes (TLR family genes, MYD88 and IRAK1/2), and the cell adhesion molecules (ICAM/LFA) were all downregulated, indicating that simvastatin also induces NB4 cell apoptosis through the inhibition of the expression of genes involved in the inflammation signal transduction pathway. This subsequently suppresses cell transcriptional activity. The activation of NF- $\mathrm{NB}$ can suppress cell apoptosis through regulating the gene expression of the IAPs family, the Bcl-2 family, the RAF family, JNK, FLIP and A20, however, the manner by which these proteins suppress cell apoptosis is not fully understood (8). Thus, suppression of $\mathrm{NF}-\kappa \mathrm{B}$ activation in cancer cells, and the subsequent induction of cell apoptosis may provide an additional target for the treatment of immune disease, inflammation and malignant tumors.

In summary, the use of simvastatin in vitro inhibits human acute promyelocytic leukemia NB4 cell proliferation and induces apoptosis in a time- and dose-dependent manner. The mechanism behind this may be associated with the regulation of the expression of genes involved in the TLR-mediated inflammatory response and $\mathrm{NF}-\kappa \mathrm{B}$ signaling pathways.

\section{Acknowledgements}

The authors are grateful to Dr Zixing Chen and Dr Jiannong Cen for their assistance in analyzing the PCR array data and in the statistical analysis. This study was supported by the 135 Opening Project of Jiangsu Province, China (KF200947).

\section{References}

1. Sassano A and Platanias LC: Statins in tumor suppression. Cancer Lett 260: 11-19, 2008

2. Hindler K, Cleeland CS, Rivera E and Collard CD: The role of statins in cancer therapy. Oncologist 11: 306-315, 2006.

3. Sivaprasad U, Abbas T and Dutta A: Differential efficacy of 3-hydroxy-3-methylglutaryl CoA reductase inhibitors on the cell cycle of prostate cancer cells. Mol Cancer Ther 5: 2310-2316, 2006 . 
4. Campbell MJ, Esserman LJ, Zhou Y, et al: Breast cancer growth prevention by statins. Cancer Res 66: 8707-8714, 2006.

5. Martirosyan A, Clendening JW, Goard CA and Penn LZ: Lovastatin induces apoptosis of ovarian cancer cells and synergizes with doxorubicin: potential therapeutic relevance. BMC Cancer 10: 103, 2010.

6. Sassano A, Katsoulidis E, Antico G, et al: Suppressive effects of statins on acute promyelocytic leukemia cells. Cancer Res 67: 4524-4532, 2007.

7. Escárcega RO, Fuentes-Alexandro S, García-Carrasco M, Gatica A and Zamora A: The transcription factor nuclear factor-kappa B and cancer. Clin Oncol (R Coll Radiol) 19: 154-161, 2007.

8. Bharti AC and Aggarwal BB: Nuclear factor-kappa B and cancer: its role in prevention and therapy. Biochem Pharmacol 64 883-888, 2002.

9. Ahn KS, Sethi G and Aggarwal BB: Reversal of chemoresistance and enhancement of apoptosis by statins through down-regulation of the NF-kappaB pathway. Biochem Pharmacol 75: 907-913, 2008.

10. Dai Y, Khanna P, Chen S, Pei XY, Dent P and Grant S: Statins synergistically potentiate 7-hydroxystaurosporine (UCN-01) lethality in human leukemia and myeloma cells by disrupting Ras farnesylation and activation. Blood 109: 4415-4423, 2007.

11. Tomiyama N, Matzno S, Kitada C, Nishiguchi E, Okamura N and Matsuyama K: The possibility of simvastatin as a chemotherapeutic agent for all-trans retinoic acid-resistant promyelocytic leukemia. Biol Pharm Bull 31: 369-374, 2008.
12. van der Weide K, de Jonge-Peeters SD, Kuipers F, de Vries EG and Vellenga E: Combining simvastatin with the farnesyltransferase inhibitor tipifarnib results in an enhanced cytotoxic effect in a subset of primary CD $34^{+}$acute myeloid leukemia samples. Clin Cancer Res 15: 3076-3083, 2009.

13. Toubi E and Shoenfeld Y: Toll-like receptors and their role in the development of autoimmune diseases. Autoimmunity 37: 183-188, 2004

14. Bassères DS and Baldwin AS: Nuclear factor-kappaB and inhibitor of kappaB kinase pathways in oncogenic initiation and progression. Oncogene 25: 6817-6830, 2006.

15. Courtois G and Gilmore TD: Mutations in the NF-kappaB signaling pathway: implications for human disease. Oncogene 25: 6831-6843, 2006.

16. Pasare $\mathrm{C}$ and Medzhitov R: Toll-like receptors: linking innate and adaptive immunity. Adv Exp Med Biol 560: 11-18, 2005.

17. Suzuki N, Suzuki S, Duncan GS, et al: Severe impairment of interleukin-1 and Toll-like receptor signalling in mice lacking IRAK-4. Nature 416: 750-756, 2002.

18. Ninomiya-Tsuji J, Kishimoto K, Hiyama A, Inoue J, Cao Z and Matsumoto K: The kinase TAK1 can activate the NIK-I kappaB as well as the MAP kinase cascade in the IL-1 signalling pathway. Nature 398: 252-256, 1999. 